ISSN 1678-3921

Journal homepage: www.embrapa.br/pab

For manuscript submission and journal contents, access: www.scielo.br/pab

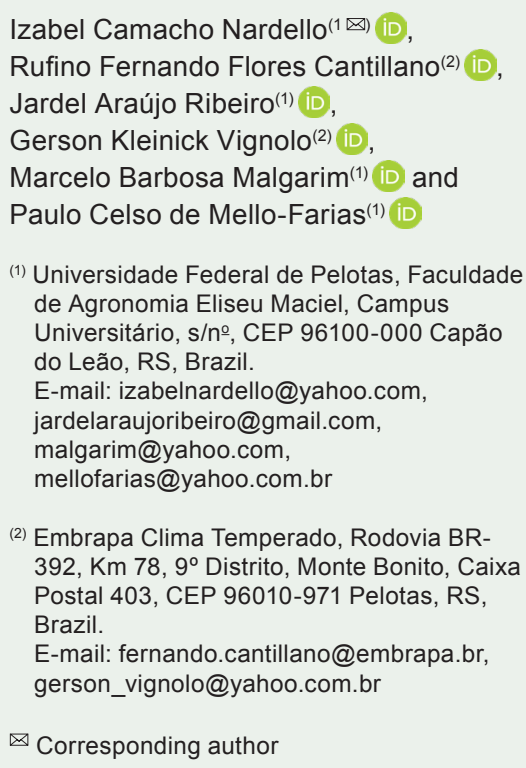

\section{Quality of strawberries subjected to pre-harvest UV-C radiation}

\begin{abstract}
The objective of this work was to evaluate the influence of the use of UV-C radiation at an intensity of $0.53 \mathrm{KJ} \mathrm{m}^{-2}$, during strawberry (Fragaria $\mathrm{x}$ ananassa) cultivation, on the physicochemical and phytochemical parameters of the fruits. The used experimental design was completely randomized, in a single-factor arrangement with 11, 19, 29, and $39 \mathrm{UV}-\mathrm{C}$ applications and without UV-C application. The hue of the fruits was smaller at the end of the study period. $\mathrm{pH}$ varied in strawberries that received 39 applications of UV$\mathrm{C}$, and the soluble solids content differed with 19 applications. Antioxidant activity was lower in fruits with 11, 19, and 29 UV-C applications, whereas vitamin $\mathrm{C}$ content was lower only in fruits that received 29 applications. The use of UV-C radiation at an intensity of $0.53 \mathrm{KJ} \mathrm{m}^{-2}$, during strawberry cultivation, affects the physicochemical and phytochemical parameters of the fruits, but does not cause losses in their quality.
\end{abstract}

Index terms: Fragaria x ananassa, cultivation, nutritional characteristics, physical characteristics, ultraviolet application.

\section{Qualidade de morangos submetidos à radiação UV-C pré-colheita}

Resumo - O objetivo deste trabalho foi avaliar a influência do uso de radiação UV-C na intensidade de $0,53 \mathrm{KJ} \mathrm{m}^{-2}$, durante o cultivo de morango (Fragaria $\mathrm{x}$ ananassa), sobre os parâmetros físico-químicos e fitoquímicos dos frutos. $\mathrm{O}$ delineamento experimental utilizado foi inteiramente casualizado, em arranjo unifatorial, com 11, 19, 29 e 39 aplicações de UV-C e sem aplicação de UV-C. A tonalidade dos frutos apresentou menor ângulo ao final do período de estudo. O pH variou em morangos que receberam 39 aplicações de UVC, e o conteúdo de sólidos solúveis diferiu com 19 aplicações. A atividade antioxidante foi menor nas frutas com 11, 19 e 29 aplicações de UV-C, enquanto o teor de vitamina $\mathrm{C}$ foi menor apenas nas frutas que receberam 29 aplicações. O uso de radiação UV-C de $0,53 \mathrm{KJ} \mathrm{m}^{-2}$, durante o cultivo de morango, afeta os parâmetros físico-químicos e fitoquímicos dos frutos, mas não leva à perda de sua qualidade.

Termos para indexação: Fragaria x ananassa, cultivo, características nutricionais, características físicas, aplicação ultravioleta.

\section{Introduction}

The Brazilian production of strawberries of approximately 100 thousand tons per year does not meet the demand for internal consumption (Reisser Junior \& Antunes, 2016), which has been 
increasing due to the characteristics of the fruit, rich in bioactive compounds, especially ascorbic acid and phenolic compounds (Cerezo et al., 2010; Giampieri et al., 2012; Lafarga et al., 2019).

One of the environmentally friendly approaches to control undesirable microorganisms, including pathogens, in strawberry plants is the UV-C treatment (Takeda et al., 2019). In fruit farming, it has either been used in postharvest treatments to decrease disease incidence and severity (Chitarra \& Chitarra, 2005) or applied to plants in the fructification stage (preharvest) to stimulate their resistance and potentialize compounds that are beneficial to health (Ramakrishna \& Ravishankar, 2011).

Some studies have shown that plant exposure to UV-C radiation may induce the synthesis of metabolites, which have antioxidant properties originating from the secondary metabolism and act to defend cell oxidation and promote positive responses, such as a delay in fruit ripening and an increase in fruit preservation postharvest (Baka et al., 1999; Pombo et al., 2011). However, that technique should be applied cautiously, since it may cause undesirable effects if used incorrectly, including changes in the color and texture of plant tissues (Oliveira et al., 2016). The intensity of UV-C radiation needed to reach positive effects on the control of pathogens and insects varies, as well as plant tolerance to radiation (Chitarra \& Chitarra, 2005).

Despite the technical efforts to select new strawberry cultivars, due to crop cultivation and management, there are still large fruit quality and quantity losses from the field to the consumer's table (Reisser Junior \& Antunes, 2016). Therefore, alternative control methods are necessary, with improved techniques for their preharvest application, in order to minimize losses and increase fruit quality. The use of ultraviolet light during the cultivation stage, for example, aids in the control of pathogens and diseases, reducing losses and improving the quality of products, without harming the environment, producer, and consumer (Oliveira et al., 2012).

The objective of this work was to evaluate the influence of the use of UV-C radiation at an intensity of $0.53 \mathrm{KJ} \mathrm{m}^{-2}$, during strawberry (Fragaria x ananassa Duch.) cultivation, on the physicochemical and phytochemical characteristics of the fruits.

\section{Materials and Methods}

The experiment was carried out in a greenhouse at Embrapa Clima Temperado, located in the municipality of Pelotas, in the state of Rio Grande do Sul, Brazil $\left(31^{\circ} 41^{\prime} \mathrm{S}, 52^{\circ} 21^{\prime} \mathrm{W}\right.$, at an altitude of $\left.60 \mathrm{~m}\right)$.

The experimental design used was completely randomized, in a single-factor arrangement, to test the effect of the application of UV-C radiation during the cultivation of strawberry plants. The treatment factor was: number of applications $(11,19,29$, and 39) and no application (control). The experimental unit consisted of 15 fruits with three replicates.

Eighty strawberry seedlings of the Albion cultivar, obtained from a private property located in the interior of Pelotas, were used. The seedlings were soon transplanted to a greenhouse in July 2016, where they were arranged on benches, with a $15 \mathrm{~cm}$ spacing between plants, in an soilless cultivation system with carbonized rice husk.

The fertigation management used was intermittent, lasting 15 min every 2 hours during plant cultivation. The water reservoir was supplied with the following commercial fertilizers manufactured by Samo Fertilizantes (Feliz, RS, Brazil): Ferti Base, at a rate of $1.0 \mathrm{~L}$ per 1,000 L of water; Ferti Morango, at a rate of $1.5 \mathrm{~L}$ per 1,000 of water; and Blum $\mathrm{P}$, at a rate of $70 \mathrm{~g}$ per 1,000 plants.

The effect of the accumulation of UV-C applications over the production cycle was evaluated. For this, of the assessed plants, 40 received the application of UV-C light and 40 did not. The harvest point adopted was when $75-100 \%$ of the fruit surface showed a red color after the plants accumulated 11, 19, 29, and 39 applications of UV-C light.

In each application, radiation at an intensity of approximately $0.53 \mathrm{KJ} \mathrm{m}^{-2}$ was applied after full bloom, during $10 \mathrm{~min}$, three times a week. For this, 30 W Phillips UV-C lamps (Philips do Brasil, Barueri, SP, Brazil) were used, distanced approximately $1 \mathrm{~m}$ from the upper part of the plants.

Fruits were taken to the postharvest laboratory of the Food Department of Embrapa Clima Temperado, where their phytochemical and physicochemical parameters were evaluated.

The analyzed physicochemical parameters were: $\mathrm{pH}$, soluble solids content, titratable acidity, and fruit firmness, and color. 
$\mathrm{pH}$ was quantified directly in the juice of strawberries using the M 780 digital pH meter (Metrohm AG, Herisau, Switzerland). Soluble solids content was also quantified directly in the juice, but with the PAL-1 digital refractometer (Atago Co. Ltd., Tokyo, Japan), by measuring the sample's refractive index, with results expressed in ${ }^{\circ}$ Brix.

Titratable acidity was obtained using $1.0 \mathrm{~mL}$ of juice, to which $90 \mathrm{~mL}$ distilled water were added; the sample was then titrated with the aid of the Brand digital burette (Brand GMBH + CO KG, Wertheim, Germany), containing $0.092 \mathrm{~N}$ sodium hydroxide solution $(\mathrm{NaOH})$, until reaching $\mathrm{pH} 8.1$, and the result was expressed in grams of citric acid $100 \mathrm{~g}^{-1}$ of juice. The relationship (ratio) between soluble solids and titratable acidity was calculated by dividing the results of soluble solids content ( ${ }^{\circ}$ Brix) and titratable acidity (percentage of citric acid).

The firmness of the fruits was determined with the aid of the TA.XT PLUS electronic texture analyzer (Extralab Brasil, Itatiba, SP, Brazil), using a $2 \mathrm{~mm}$ diameter tip with a pre-test speed of $1.0 \mathrm{~mm}$ per $\mathrm{s}^{-1}$, a test speed of $2.0 \mathrm{~mm} \mathrm{~s}^{-1}$, a post-test speed of 10.0 $\mathrm{mm} \mathrm{s}^{-1}$, and a force of $5 \mathrm{~kg}$, with results expressed in Newton.

For color measurement, the CR 400 digital colorimeter was used (Konica Minolta Sensing Americas, Ramsey, NJ, USA), with the CIE L* $a^{*} b^{*}$ reading system proposed by Commission Internationale de I'Eclairage (Vienna, Austria) and with chromatic shade or tint, represented by the Hue angle $\left(\mathrm{H}^{\circ}\right)$, using the formula arc tangent $\mathrm{b}^{*} / \mathrm{a}^{*}$, whose results were expressed as degrees.

The phytochemical parameters (total anthocyanins, antioxidant activity, and vitamin $\mathrm{C}$ content) were obtained through spectrophotometry, using the Evolution 60S equipment (Thermo Fisher Scientific, Madison, WI, USA). The content of total anthocyanins was determined according to methodology adapted from Fuleki \& Francis (1968), by adding $5 \mathrm{~g}$ of the sample to $15 \mathrm{~mL}$ of a solvent $(95 \%$ ethanol with 1.5 $\mathrm{N} \mathrm{HCL}$, at the proportion of 85:15); the readings were made at $535 \mathrm{~nm}$, and the result was expressed in milligram of cyanidin 3-glucoside per $100 \mathrm{~g}$ of sample.

For antioxidant activity (DPPH), the method of Brand-Williams et al. (1995), with some modifications, was used. A total of $250 \mu \mathrm{L}$ of the sample was pipetted and allowed to react with $3,750 \mu \mathrm{L}$ of the DPPH solution diluted in methanol for 24 hours in the dark. After this period, absorbance was read at $515 \mathrm{~nm}$ using the calibration curve of linear range, whose results were expressed as mg Trolox $100 \mathrm{~g}^{-1}$ of fresh fruit.

Vitamin C content (mg of ascorbic acid per $100 \mathrm{~g}$ of fresh fruit) was obtained using the methodology proposed by Oliveira et al. (2010). Total phenol content was determined by the methodology of Swain $\&$ Hillis (1959), with adaptations, by pipetting $250 \mu \mathrm{L}$ of the sample into test tubes, to which $4.0 \mathrm{~mL}$ of ultrapure water and $250 \mu \mathrm{L}$ of the Folin-Ciocalteau reagent $(0.25 \mathrm{~N})$ were added, allowing the solution to rest for $3 \mathrm{~min}$, then adding $500 \mu \mathrm{L}$ of sodium carbonate $(1.0 \mathrm{~N})$ and allowing the solution to rest for another 2 hours; absorbance (mg gallic acid $100 \mathrm{~g}^{-1}$ of fresh fruit) was read by a spectrophotometer with a wavelength of $725 \mathrm{~nm}$.

The obtained results were subjected to the analysis of variance by the F-test $(p \leq 0.05)$. In the case of statistical significance, Dunnet's test $(p \leq 0.05)$ was used to evaluate the effect of the number of UV-C applications in relation to the control (without UVC) and Tukey's test $(p \leq 0.05)$, among the number of applications.

\section{Results and Discussion}

Between UV-C applications and the control, $\mathrm{pH}$ varied for 39 applications, whereas, among applications, the highest $\mathrm{pH}$ values were found for 19 and 29 applications (Table 1). Despite the statistical difference observed between the treatments, $\mathrm{pH}$ variation did not change the quality of the fruits, which is interesting since $\mathrm{pH}$ is an important intrinsic factor for the development of food microorganisms (Ferreira et al., 2015).

The content of soluble solids differed significantly only with 19 applications of UV-C (Table 1) in comparison with the control. When comparing the number of applications, the highest values were found at the beginning (11 applications) and at the end (39 applications) of the treatment. This result may be related to the environmental conditions to which the plants were subjected, since a similar trend was observed for fruits that did not receive additional radiation. Xie et al. (2016), in a study of UV-C radiation applied to strawberry in pre-harvest, reported that season and cultivar play a more important role in the quality of the fruits than the UV-C treatment during plant growth. 
Titratable acidity did not differ in relation to the control for any of the UV-C applications (Table 1). However, the treatment that received 19 applications had the lowest value, which was similar to that of the control plants. In fruits, this parameter usually tends to increase throughout their growth until their complete physiological development, decreasing as they ripen (Chitarra \& Chitarra, 2005).

The variables ratio and firmness also did not differ significantly by the analysis of variance at $\operatorname{Pr}>\mathrm{F} 0.18$ and 0.05 , respectively.

Regarding the shade of the fruits, there was a significant difference only at the end of the study period (Table 1), when the fruits that received 39 UV-C applications showed a greater Hue angle than the control. It was observed that the value of the Hue angle decreased as the number of applications increased. This translates into an intensification of the red color with the increase in the number of UV-C applications: at the end of the experiment, strawberries that received 39 applications showed a more intense red color than those that were not irradiated. Oliveira et al. (2016) also found that strawberries that received $\mathrm{UV}-\mathrm{C}$ radiation had a lower Hue angle. Once again, although the physicochemical attributes differed significantly between treatments, there was no loss of fruit quality under UV-C radiation when compared with the control.

The content of total anthocyanins in the fruits of plants that received 11 and 19 applications of UV-C differed significantly from that of those of the control (Table 2). Among the fruits that received radiation, there was an increase in the content of anthocyanins after 19 applications. This may explain the increase in color intensity, previously mentioned, since these compounds are the main promoters of red color in these fruits (Severo et al., 2011). Sun et al. (2020) identified cyanidin-3-O-glucoside, pelargonidin-3-O-glucoside, pelargonidin-3-O-rutinoside, and pelargonidin-3$\mathrm{O}$-acetylgluoside as the four main anthocyanins in strawberries of the Chandler cultivar irradiated twice a week during pre-harvest, whereas Oliveira et al. (2016)

Table 1. Average pH contents, soluble solids (SS), titratable acidity (TA), and hue of fruits of the Albion strawberry (Fragaria $\mathrm{x}$ ananassa) cultivar subjected to different numbers of pre-harvest UV-C radiation applications ${ }^{(1)}$.

\begin{tabular}{|c|c|c|c|c|c|c|c|c|}
\hline \multirow[t]{2}{*}{$\begin{array}{l}\text { Number of } \\
\text { applications }\end{array}$} & \multicolumn{2}{|c|}{$\mathrm{pH}$} & \multicolumn{2}{|c|}{$\begin{array}{c}\text { SS } \\
\left({ }^{\circ} \text { Brix }\right) \\
\end{array}$} & \multicolumn{2}{|c|}{$\begin{array}{l}\text { TA (grams of citric acid } \\
100 \mathrm{~g}^{-1} \text { of juice) }\end{array}$} & \multicolumn{2}{|c|}{$\begin{array}{l}\text { Hue } \\
\left({ }^{\circ} \mathrm{H}\right)\end{array}$} \\
\hline & Without UV-C & With UV-C & Without UV-C & With UV-C & Without UV-C & With UV-C & Without UV-C & With UV-C \\
\hline 11 & $3.5 \mathrm{~ns}$ & $3.5 \mathrm{ab}$ & $9.3 \mathrm{~ns}$ & $8.7 \mathrm{ab}$ & $1.0 \mathrm{~ns}$ & $1.2 \mathrm{a}$ & $33.1 \mathrm{~ns}$ & $33.4 \mathrm{a}$ \\
\hline 19 & $3.6 \mathrm{~ns}$ & $3.6 \mathrm{a}$ & $7.6^{*}$ & $7.0 \mathrm{c}$ & $0.9 \mathrm{~ns}$ & $0.8 \mathrm{c}$ & $30.1 \mathrm{~ns}$ & $32.0 \mathrm{ab}$ \\
\hline 29 & $3.6 \mathrm{~ns}$ & $3.6 \mathrm{a}$ & $9.1 \mathrm{~ns}$ & $7.9 \mathrm{bc}$ & $1.0 \mathrm{~ns}$ & $1.0 \mathrm{~b}$ & $31.6 \mathrm{~ns}$ & $28.9 b$ \\
\hline 39 & $3.6^{*}$ & $3.4 \mathrm{~b}$ & $10.4 \mathrm{~ns}$ & $9.7 \mathrm{a}$ & $1.2 \mathrm{~ns}$ & $1.1 \mathrm{ab}$ & $26.5^{*}$ & $28.6 \mathrm{~b}$ \\
\hline CV (\%) & \multicolumn{2}{|c|}{1.59} & \multicolumn{2}{|c|}{5.58} & \multicolumn{2}{|c|}{8.11} & \multicolumn{2}{|c|}{5.44} \\
\hline
\end{tabular}

${ }^{(1)}$ Means followed by equal letters, in the columns, do not differ by Tukey's test, at $5 \%$ probability. *Significant by Dunnet's test, at $5 \%$ probability.

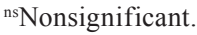

Table 2. Average contents of anthocyanins, antioxidant activity, vitamin $\mathrm{C}$, and total phenols of fruits of the Albion strawberry (Fragaria x ananassa) cultivar subjected to different numbers of pre-harvest UV-C radiation applications ${ }^{(1)}$.

\begin{tabular}{|c|c|c|c|c|c|c|c|c|}
\hline \multirow{2}{*}{$\begin{array}{l}\text { Number of } \\
\text { applications }\end{array}$} & \multicolumn{2}{|c|}{ Anthocyanins $^{(2)}$} & \multicolumn{2}{|c|}{ Antioxidant activity $^{(3)}$} & \multicolumn{2}{|c|}{ Vitamin $C^{(4)}$} & \multicolumn{2}{|c|}{ Total phenols $^{(5)}$} \\
\hline & Without UV-C & With UV-C & Without UV-C & With UV-C & Without UV-C & With UV-C & Without UV-C & With UV-C \\
\hline 11 & $94.5^{*}$ & $60.3 b$ & $439.1^{*}$ & $346.0 \mathrm{~b}$ & $44.8^{\mathrm{ns}}$ & $44.9 \mathrm{~b}$ & $160.6^{\mathrm{ns}}$ & $141.7 \mathrm{c}$ \\
\hline 19 & $71.2^{*}$ & $144.8 \mathrm{a}$ & $317.8^{*}$ & $403.2 \mathrm{a}$ & $31.3^{\mathrm{ns}}$ & $36.8 b$ & $143.8^{\mathrm{ns}}$ & $141.8 \mathrm{bc}$ \\
\hline 29 & $161.3^{\mathrm{ns}}$ & $111.9 \mathrm{a}$ & $305.2^{*}$ & $271.1 \mathrm{c}$ & $42.6^{*}$ & $37.7 b$ & $168.1^{\mathrm{ns}}$ & $165.7 \mathrm{ab}$ \\
\hline 39 & $147.1^{\mathrm{ns}}$ & $155.4 \mathrm{a}$ & $493.9^{\text {ns }}$ & $447.7 \mathrm{a}$ & $67.0^{\text {ns }}$ & $59.1 \mathrm{a}$ & $175.4^{\mathrm{ns}}$ & $177.8 \mathrm{a}$ \\
\hline$\overline{C V}(\%)$ & \multicolumn{2}{|c|}{26.78} & \multicolumn{2}{|c|}{10.45} & \multicolumn{2}{|c|}{9.51} & \multicolumn{2}{|c|}{6.72} \\
\hline
\end{tabular}

${ }^{(1)}$ Means followed by equal letters, in the columns, do not differ by Tukey's test, at $5 \%$ probability. ${ }^{(2)}$ Milligram of cyanidin 3 -glucoside per $100 \mathrm{~g}$ of fresh fruit. ${ }^{(3)}$ Milligram of Trolox per $100 \mathrm{~g}$ of fresh fruit. ${ }^{(4)}$ Milligram of ascorbic acid per $100 \mathrm{~g}$ of fresh fruit. ${ }^{(5)}$ Milligram of gallic acid per $100 \mathrm{~g}$ of fresh fruit. *Significant by Dunnet's test, at $5 \%$ probability. ${ }^{\text {ns }}$ Nonsignificant. 
found an increase in the content of anthocyanins in strawberries irradiated in pre-harvest.

Antioxidant activity varied with the application of UV-C during cultivation (Table 2), being lower in fruits irradiated with 11 and 29 applications in comparison with the control. This result differed from what was expected, since stress induction can promote the activation of the secondary metabolism, increasing the induction of antioxidant compounds, such as phenolic compounds, vitamin C, and anthocyanins (Kim et al., 2002; Keutgen \& Pawelzik, 2007; Zushi \& Matsuzoe, 2007; Pombo et al., 2011).

Silva et al. (2011), however, observed photoinhibitory damage in photosystem II when applying UV-C radiation to soybean (Glycine max L.) plants, which, according to Souza et al. (2005), can generate less reducing power for the biochemical phase of photosynthesis, decreasing carbon fixation rates and, consequently, influencing all the metabolic processes of the plant.

When comparing the number of UV-C applications to the control, vitamin $\mathrm{C}$ content differed significantly only with 29 applications (Table 2), showing a value lower than that of non-irradiated fruits. However, among the number of applications, the highest concentration of vitamin $\mathrm{C}$ occurred with 39 applications. These results corroborate those of Ortiz Araque et al. (2018), who used UV-C radiation before and after storing strawberries of the Camarosa cultivar. However, Oliveira et al. (2016) reported a higher concentration of vitamin $\mathrm{C}$ in fruits irradiated in the pre-harvest stage.

The obtained results are evidence of the low antioxidant activity of irradiated fruits. However, there is little information about the biochemical and physiological responses of fruits and vegetables treated with UV-C during pre-harvest to thoroughly explain how phytochemical compounds and antioxidant capacity are affected by the application of UV-C preharvest.

The content of total phenols differed significantly only for the number of UV-C applications, showing a greater accumulation with 39 applications (Table 2). This increase may be related to the oxidative stress caused by the application of UV-C. De Wit (2007) suggests that the increase in the content of phenolic compounds is a form of protection of cells against the application of UV-C radiation. Moreover, as aforementioned, Xie et al. (2016) concluded that strawberry cultivar and growing season played a more important role than UV-C treatment in the phenolic metabolism of fruits.

In general, fruit physicochemical and phytochemical compounds are altered by the number of applications of UV-C radiation on the plants during cultivation; however, this variation is not enough to change the quality characteristics of strawberries. The individual behavior of each species and cultivar in face of the stress caused by application of UV-C radiation should also be considered, which requires adapting application intensity and rate according to production interest.

\section{Conclusion}

The use of UV-C radiation at an intensity of 0.53 $\mathrm{KJ} \mathrm{m}^{-2}$, during strawberry (Fragaria $\mathrm{x}$ ananassa) cultivation, affects the physicochemical and phytochemical parameters of the fruits, but does not cause losses in their quality.

\section{Acknowledgments}

To Coordenação de Aperfeiçoamento de Pessoal de Nível Superior (Capes), for financing, in part, this study (Finance Code 001).

\section{References}

BAKA, M.; MERCIER, J.; CORCUFF, R.; CASTAIGNE, F.; ARUL, J. Photochemical treatment to improve storability of fresh strawberries. Journal of Food Science, v.64, p.1068-1072, 1999. DOI: https://doi.org/10.1111/j.1365-2621.1999.tb12284.x.

BRAND-WILLIAMS, W.; CUVELIER, M.E.; BERSET, C. Use of a free radical method to evaluate antioxidant activity. LWT - Food Science and Technology, v.28, p.25-30, 1995. DOI: https://doi.org/10.1016/S0023-6438(95)80008-5.

CEREZO, A.B.; CUEVAS, E.; WINTERHALTER, P.; GARCIAPARRILLA, M.C.; TRONCOSO, A.M. Isolation, identification, and antioxidant activity of anthocyanin compounds in Camarosa strawberry. Food Chemistry, v.123, p.574-582, 2010. DOI: https://doi.org/10.1016/j.foodchem.2010.04.073.

CHITARRA, M.I.F.; CHITARRA, A.B. Pós-colheita de frutas e hortaliças: fisiologia e manuseio. 2.ed. atual e ampl. Lavras: UFLA, 2005. 783p.

de WIT, P.J.G.M. How plants recognize pathogens and defend themselves. Cellular and Molecular Life Sciences, v.64, p.27262732, 2007. DOI: https://doi.org/10.1007/s00018-007-7284-7.

FERREIRA, A.B.; ALVARENGA, S.H.F. de; SÃO JOSÉ, J.F.B. de. Qualidade de frutas e hortaliças orgânicas comercializadas em feiras livres. Revista do Instituto Adolfo Lutz, v.74, p.410419, 2015. 
FULEKI, T.; FRANCIS, F.J. Quantitative methods for anthocyanins. Journal of Food Science, v.33, p.72-77, 1968. DOI: https://doi.org/10.1111/j.1365-2621.1968.tb00887.x.

GIAMPIERI, F.; TULIPANI, S.; ALVAREZ-SUAREZ, J.M.; QUILES, J.L.; MEZZETTI, B.; BATTINO, M. The strawberry: composition, nutritional quality, and impact on human health. Nutrition, v.28, p.9-19, 2012. DOI: https://doi.org/10.1016/j. nut.2011.08.009.

KEUTGEN, A.J.; PAWELZIK, E. Modifications of strawberry fruit antioxidant pools and fruit quality under $\mathrm{NaCl}$ stress. Journal of Agricultural and Food Chemistry, v.55, p.40664072, 2007. DOI: https://doi.org/10.1021/jf070010k.

KIM, D.-O.; LEE, K.W.; LEE, H.J.; LEE, C.Y. Vitamin C equivalent antioxidant capacity (VCEAC) of phenolic phytochemicals. Journal of Agricultural and Food Chemistry, v.50, p.37133717, 2002. DOI: https://doi.org/10.1021/jf020071c.

LAFARGA, T.; RUIZ-AGUIRRE, I.; ABADIAS, M.; VIÑAS, I.; BOBO, G.; AGUILÓ-AGUAYO, I. Effect of thermosonication on the bioaccessibility of antioxidant compounds and the microbiological, physicochemical, and nutritional quality of an anthocyanin-enriched tomato juice. Food and Bioprocess Technology, v.12, p.147-157, 2019. DOI: https://doi.org/10.1007/ s11947-018-2191-5.

OLIVEIRA, I.R. de; CRIZEL, G.R.; LEITE, T.B.; CANTILLANO, R.F.F.; ROMBALDI, C.V. Influência no teor de fitoquímicos em morangos tratados com diferentes aplicações de radiação UV-C durante o cultivo. In: CONGRESSO BRASILEIRO DE FrUtiCUlturA, 22., 2012, Bento Gonçalves. Anais. Bento Gonçalves: SBF, 2012. Coordenação: Luis Eduardo Correa Antunes, Paulo Ricardo Dias Oliveira e João Caetano Fioravanço.

OLIVEIRA, I.R. de; CRIZEL, G.R.; SEVERO, J.; RENARD, C.M.G.C.; CHAVES, F.C.; ROMBALDI, C.V. Preharvest UV-C radiation influences physiological, biochemical, and transcriptional changes in strawberry cv. Camarosa. Plant Physiology and Biochemistry, v.108, p.391-399, 2016. DOI: https://doi.org/10.1016/j.plaphy.2016.08.012.

OLIVEIRA, R.G. de; GODOY, H.T.; PRADO, M.A. Otimização de metodologia colorimétrica para a determinação de ácido ascórbico em geleias de frutas. Ciência e Tecnologia de Alimentos, v.30, p.244-249, 2010. DOI: https://doi.org/10.1590/ S0101-20612010000100036.

ORTIZ ARAQUE, L.C.; RODONI, L.M.; DARRÉ, M.; ORTIZ, C.M.; CIVELLO, P.M.; VICENTE, A.R. Cyclic low dose UV-C treatments retain strawberry fruit quality more effectively than conventional pre-storage single high fluence applications. LWT - Food Science and Technology, v.92, p.304-311, 2018. DOI: https://doi.org/10.1016/j.lwt.2018.02.050.

POMBO, M.A.; ROSLI, H.G.; MARTÍNEZ, G.A.; CIVELLO, P.M. UV-C treatment affects the expression and activity of defense genes in strawberry fruit (Fragaria $\times$ ananassa, Duch.). Postharvest Biology and Technology, v.59, p.94-102, 2011. DOI: https://doi.org/10.1016/j.postharvbio.2010.08.003.

RAMAKRISHNA, A.; RAVISHANKAR, G.A. Influence of abiotic stress signals on secondary metabolites in plants. Plant Signaling \& Behavior, v.6, p.1720-1731, 2011. DOI: https://doi.org/10.4161/psb.6.11.17613.

REISSER JUNIOR, C.; ANTUNES, L.E.C. Morangos: o cultivo no Brasil. Campo \& Negócios: Hortifruti, v.128, p.44-47, 2016.

SEVERO, J.; TIECHER, A.; CHAVES, F.C.; SILVA, J.A.; ROMBALDI, C.V. Gene transcript accumulation associated with physiological and chemical changes during developmental stages of strawberry cv. Camarosa. Food Chemistry, v.126, p.995-1000, 2011. DOI: https://doi.org/10.1016/j.foodchem.2010.11.107.

SILVA, P.E. de M.; SANTIAGO, E.F.; SILVA, E.M. da; RONDON SÚAREZ, Y.; DALOSO, D. de M. Fluorescência da clorofila-a e variação da simetria como ferramentas de investigação de plantas sob estresse. Idesia, v.29, p.45-52, 2011. DOI: https://doi.org/10.4067/S0718-34292011000300007.

SOUZA, G.M.; VIANA, J. de O.F.; OLIVEIRA, R.F. de. Asymmetrical leaves induced by water deficit show asymmetric photosynthesis in common bean. Brazilian Journal of Plant Physiology, v.17, p.223-227, 2005. DOI: https://doi.org/10.1590/ S1677-04202005000200005.

SUN, J.; JANISIEWICZ, W.J.; TAKEDA, F.; EVANS, B.; JURICK II, W.M.; ZHANG, M.; YU, L.; CHEN, P. Effect of nighttime UV-C irradiation of strawberry plants on phenolic content of fruit: targeted and non-targeted metabolomic analysis. Journal of Berry Research, v.10, p.365-380, 2020. DOI: https://doi.org/10.3233/JBR-190482.

SWAIN, T.; HILLIS, W.E. The phenolic constituents of Prunus domestica. I. - The quantitative analysis of phenolic constituents. Journal of the Science of Food and Agriculture, v.10, p.63-68, 1959. DOI: https://doi.org/10.1002/jsfa.2740100110.

TAKEDA, F.; JANISIEWICZ, W.J.; SMITH, B.J.; NICHOLS, B. A new approach for strawberry disease control. European Journal of Horticultural Science, v.84, p.3-13, 2019. DOI: https://doi.org/10.17660/eJHS.2019/84.1.1.

XIE, Z.; FAN, J.; CHARLES, M.T.; CHARLEBOIS, D.; KHANIZADEH, S.; ROLLAND, D.; ROUSSEL, D.; ZHANG, Z. Preharvest ultraviolet-C irradiation: influence on physicochemical parameters associated with strawberry fruit quality. Plant Physiology and Biochemistry, v.108, p.337-343, 2016. DOI: https://doi.org/10.1016/j.plaphy.2016.07.026.

ZUSHI, K.; MATSUZOE, N. Salt stress-enhanced $\gamma$-aminobutyric acid (GABA) in tomato fruit. Acta Horticulturae, v.761, p.431435, 2007. DOI: https://doi.org/10.17660/ActaHortic.2007.761.59.

Pesq. agropec. bras., Brasília, v.56, e01590, 2021

DOI: 10.1590/S1678-3921.pab2021.v56.01590 